DOI: 10.17707/AgricultForest.64.4.01

\begin{abstract}
Juan José LÓPEZ-MARTÍN, María Remedios MORALES-CORTS*, Rodrigo PÉREZ-SÁNCHEZ, María Ángeles GÓMEZ-SÁNCHEZ ${ }^{1}$
\end{abstract}

\title{
EFFICIENCY OF GARDEN WASTE COMPOST TEAS ON POTATO GROWTH AND ITS SUPPRESSIVENESS AGAINST RHIZOCTONIA
}

\section{SUMMARY}

Compost teas are organic solutions obtained by the fermentation of compost in a liquid phase for a few days, with or without aeration. The use of these teas in agriculture is emerging for supplementing or substituting fertilizers and for their ability to suppress soil-borne pathogens. In this study physical and chemical characterization of garden waste compost tea, its application effects on potato growth and its suppressive effect against Rhizoctonia solani were analyzed. $\mathrm{N}$ and $\mathrm{K}$ content were relevant (3200 and $3848 \mathrm{ppm}$, respectively). Humic acid level was $190 \mathrm{mg} \mathrm{L}^{-1}$. Field trials were carried out with three fried industrial cultivars (Agria, Hermes and Lady Amarilla) in soils affected by Rhizoctonia located in Rasueros municipality (Avila, Spain) during 2017. Different dosages of compost tea ( $\mathrm{d} 1: 1 \mathrm{l}$ and $\mathrm{d} 2: 31$ per plot-7.5 $\mathrm{m}^{2}$ ) were applied in experimental potato crops, in order to evaluate growth and production parameters (plant height, SPA units, shoots number, yield, tuber size and fried quality) and the Rhizoctonia solani control (attack severity). The application of the dosage 1 (1333,3 $\left.\mathrm{l} \mathrm{ha}^{-1}\right)$, with respect to control, increased the yield $(9,47 \%)$, improved the culinary quality (40\%) and reduced the Rhizoctonia incidence (12,4-23,7\%). These results show that the use of garden waste compost tea can be of great interest to organic and sustainable agriculture.

Keywords: Solanum tuberosum, Organic fertilizer, Biological control, Rhizoctonia solani.

\section{INTRODUCTION}

Nowadays, potato (Solanum tuberosum L.) is the fourth important crop in the world (FAO, 2016) and millions of people depend directly from it for their food, being a staple in the diet, and driving the rural economy of entire regions in the world, especially in Latin America. This crop suffers from the attack of several diseases that affect its production, being one of the main Rhizoctonia solani Kühn, a fungus causing losses of up to $30 \%$ of the production, with the consequent reduction in economic yield and loss of food for the population. This

\footnotetext{
${ }^{1}$ Juan José López-Martín, María Remedios Morales-Corts*(corresponding author: reme@usal.es), Rodrigo Pérez-Sánchez, María Ángeles Gómez-Sánchez, Crop Production Area, Faculty of Agricultural and Environmental Sciences, University of Salamanca, Avda. Filiberto Villalobos, 119. 37007, Salamanca, SPAIN

Paper presented at the $9^{\text {th }}$ International Scientific Agricultural Symposium "AGROSYM 2018".

Notes: The authors declare that they have no conflicts of interest. Authorship Form signed online.
} 
fact combined with the current limitation of active materials for phytosanitary control and the new tendencies towards an increasingly ecological agriculture, shows that there is a serious problem at a global level. It will be necessary to find new forms of phytosanitary control of the disease, maintaining the yields and the quality of the crop and at the same time respecting the environment.

Compost teas are organic solutions obtained by the fermentation of compost in a liquid phase for a few days, with or without aeration. Generally, extracts are prepared by mixing mature compost with tap water in the ratios of 1:5 to $1: 10(\mathrm{v} / \mathrm{v})$ (Al-Dahmani et al., 2003). The use of these teas in agriculture is also emerging because of their ability to suppress a wide range of both soil and airborne pathogens (Martin, 2014). Morales-Corts et al. (2018) demonstrated the high potential of garden waste aerated compost and vermicompost teas on tomato growth and the suppressive effect on $R$. solani and $F$. oxysporum f. sp. lycopersici by "in vitro" and "pot” essays. Gomez-Sánchez et al. (2017) indicated the suppressive effect on $R$. solani produced by the same compost tea applied in potato crop grown in pot.

These studies support the use of garden waste compost teas as potential alternatives to the application of synthetic fungicides, and as plant promoters in crop production, for attaining environmental sustainability for farming and food safety. Reeve et al. (2010) also indicate the potential of compost teas for supplementing or substituting other types of fertilizers also seems promising, but further testing under both greenhouse conditions and in the open field is still required.

In this sense, the aims of this study were to carry out the physical and chemical characterization of garden waste compost and to analyse its application effects on potato growth and suppressive effect against Rhizoctonia solani in field conditions.

\section{Preparation of compost teas}

MATERIAL AND METHODS

Compost was based on green and pruning residues which came from gardens in the province of Salamanca (Spain). Most of the material collected consisted of the leaves and stems of different Cupressaceae species and grass clippings. The composting process was carried out using aerated-piles measuring $15 \mathrm{~m}$ by $2 \mathrm{~m}$ (sides) and $2 \mathrm{~m}$ in height. The piles were turned twice per week over 8 weeks and once a week during the rest of the bio-oxidative process. Pile moisture was controlled weekly and the composting process lasted 180 days. Then, compost was mixed with tap water in a ratio of 1:5 ( $/ / \mathrm{v})$ in polyethylene non-degradable $1000 \mathrm{~L}$ containers at room temperature for brewing period lasting 5 days. Water had been previously aerated for $8 \mathrm{~h}$ to reduce the amount of chlorines present in it. The mixtures were aerated using an aquarium pump ( $4 \mathrm{~h}$ every day). Next, the liquid was filtered through a double layered cheesecloth to obtain the aerated compost tea which was stored in dark polyethylene containers at room temperature until use. 


\section{Analytical characterization of compost tea}

The $\mathrm{pH}$ and electrical conductivity (EC) were determined by using a CRISON pH-meter and a CRISON EC-meter $\left(\mathrm{dS} \mathrm{m}^{-1}\right)$, respectively. Total $\mathrm{N}$ was determined by a LECO-device analyser. $\mathrm{P}_{2} \mathrm{O}_{5}, \mathrm{~K}_{2} \mathrm{O}, \mathrm{S}$, Ca and $\mathrm{Mg}$ were analysed by a HANNA HI 993310 photometer. Humic acids were determined using the alkali/acid fractionation method following the procedure indicated by Pant et al. (2012). Nine samples of the compost tea were analysed and the means of the parameters were calculated.

\section{Potato production assays}

Field assays were carried out in soils affected by Rhizoctonia located in Rasueros municipality (Avila, Spain) during 2017. The growing region is $800 \mathrm{~m}$ above sea level and has an annual average temperature of $12.2^{\circ} \mathrm{C}$ and an annual precipitation of $375 \mathrm{~mm}$ (continental mediterranean climate). The value of the soil $\mathrm{pH}$ is 7.7 and materia organic content $1 \%$. Three fried industrial cultivars were employed for the assays: Agria, Hermes and Lady Amarilla. Their sensibilities to Rhizoctonia are different. Hermes cultivar presents some resistance to Rhizoctonia attack, Agria is a sensible cultivar and Lady Amarilla is catalogued like medium sensibility cultivar.

The assay was established on April 1, using a random block design with three plots per treatment and cultivar. Twenty eight plants per plots $\left(7.5 \mathrm{~m}^{2}\right)$ were sown in a disposition of $35 \times 75 \mathrm{~cm}$. Potatoes were collected on August 20. Different dosages of compost tea were applied as treatments in experimental potato crops (Control: no application, T1:1l per plot, T2: 31 per plot) in order to evaluate growth and production as well as the effect on the Rhizoctonia solani control (attack severity).

The first tea treatment was just applied into sowed line. The followings applications were carried out by pulverization each two weeks. Only a common pre-sow fertilization was practised and no phytosanitary products either post-sow mineral fertilizations were applied.

Analysed parameters were: Plant height (cm), chlorophyll content (SPAD502) and shoots number after three weeks from planting. Yield ( $\mathrm{kg} / \mathrm{plot})$, tuber size (mm) and fried quality were evaluated at the end of the essay. The quality for fried was assessed by simulating the industrial frying process using oil at $178^{\circ} \mathrm{C}$ for 3 minutes and determining the percentage of darkened potato slices.

Plants were watered by aspersion system when needed. Differences between treatments were determined by ANOVA and where significant differences were found, a Tukey range test $(p<0.05)$ was also carried out.

\section{RESULTS AND DISCUSSION}

Results of analytical characterization of compost tea are shown in Table 1. It is pointed that compost tea presents essential nutrients for growing plants. This fact was also described by Pant et al. (2012) who obtained similar EC values in different compost teas. $\mathrm{pH}$ was similar than others compost teas obtained from 
variable materials (Martínez, 1996; Bollo, 1999; Masciandaro et al., 2000). It is important to note that the $\mathrm{N}$ and $\mathrm{K}$ levels make this tea potentially interesting as fertilizer for growing crops. Segarra et al. (2009) supported this finding, indicating that compost tea prepared from garden wastes was rich in inorganic salts.

Table 1. Physic-chemical composition of compost tea.

\begin{tabular}{ccccccccc}
\hline $\mathrm{pH}$ & $\begin{array}{c}\mathrm{CE} \\
(\mathrm{dS} / \mathrm{m})\end{array}$ & $\begin{array}{c}\mathrm{N} \\
(\mathrm{ppm})\end{array}$ & $\begin{array}{c}\mathrm{P}_{2} \mathrm{O}_{5} \\
(\mathrm{ppm})\end{array}$ & $\begin{array}{c}\mathrm{K}_{2} \mathrm{O} \\
(\mathrm{ppm})\end{array}$ & $\begin{array}{c}\mathrm{S} \\
(\mathrm{ppm})\end{array}$ & $\begin{array}{c}\mathrm{Ca} \\
(\mathrm{ppm})\end{array}$ & $\begin{array}{c}\mathrm{Mg} \\
(\mathrm{ppm})\end{array}$ & $\begin{array}{c}\mathrm{Humic} \\
\text { acids } \\
(\% \mathrm{~ms})\end{array}$ \\
\hline 7.16 & 1.2 & $2,240.4$ & 61.4 & $2,851.2$ & 20 & 280 & 20 & 10.3 \\
\hline
\end{tabular}

However, other researchers such as Tognetti et al. (2005) obtained higher values of EC and nutrients due to the nature of the materials used for composting. In our study the content of humic acids is higher than the teas analyzed by Pant et al. (2012).

With respect to the potato production assays, Table 2 shows the results of the compost tea applications over the three cultivars.

Table 2. Growth effect on potato plants and attack severity of Rhizoctonia solani diseases using compost tea.

\begin{tabular}{|l|c|c|c|c|c|c|c|c|c|}
\hline Treatments & $\begin{array}{c}\text { Yield } \\
(\mathrm{Kg} / \mathrm{ha})\end{array}$ & $\begin{array}{c}\text { Shoot } \\
\text { High } \\
(\mathrm{cm})\end{array}$ & $\begin{array}{c}\mathrm{N}^{\mathrm{o}} \\
\text { of } \\
\text { shoots }\end{array}$ & $\begin{array}{c}\text { Chloroph. } \\
\text { content } \\
\text { (SPA } \\
\text { units) }\end{array}$ & $\begin{array}{c}\text { Tuber } \\
\text { Weight } \\
(\text { Kg) }\end{array}$ & $\begin{array}{c}\text { Tuber } \\
\text { Size } \\
(\mathrm{mm})\end{array}$ & $\begin{array}{c}\text { Number } \\
\text { of tubers } \\
\text { per plant }\end{array}$ & $\begin{array}{c}\text { Frying } \\
\text { defects } \\
\%\end{array}$ & $\begin{array}{c}\text { Rhizoctonia } \\
\text { Attack } \\
\text { severity }\end{array}$ \\
\hline Agria Control & $71,373 \mathrm{a}$ & $9.25 \mathrm{a}$ & $1.16 \mathrm{a}$ & $53.41 \mathrm{a}$ & $0.22 \mathrm{a}$ & $73.82 \mathrm{a}$ & $9.73 \mathrm{a}$ & $46.67 \mathrm{~b}$ & 11.9 \\
\hline Agria T1 & $79,524 \mathrm{~b}$ & $18.3 \mathrm{~b}$ & $2.75 \mathrm{~b}$ & $51.5 \mathrm{a}$ & $0.304 \mathrm{~b}$ & $96.38 \mathrm{~b}$ & $7.85 \mathrm{a}$ & $7.26 \mathrm{a}$ & 0 \\
\hline Agria T2 & $83,111 \mathrm{~b}$ & $20.5 \mathrm{~b}$ & $1.83 \mathrm{~b}$ & $53.8 \mathrm{a}$ & $0.332 \mathrm{~b}$ & $92.38 \mathrm{~b}$ & $7.51 \mathrm{a}$ & $8.67 \mathrm{a}$ & 0 \\
\hline $\begin{array}{l}\text { Hermes } \\
\text { Control }\end{array}$ & $85,387 \mathrm{a}$ & $13.91 \mathrm{a}$ & $2 \mathrm{a}$ & $42.85 \mathrm{a}$ & $0.207 \mathrm{a}$ & $71 \mathrm{a}$ & $12.37 \mathrm{~b}$ & $13.55 \mathrm{~b}$ & 4.76 \\
\hline Hermes T1 & $85,032 \mathrm{a}$ & $24.33 \mathrm{~b}$ & $3.33 \mathrm{~b}$ & $44.63 \mathrm{ab}$ & $0.281 \mathrm{~b}$ & $85.22 \mathrm{~b}$ & $9.08 \mathrm{ab}$ & $0 \mathrm{a}$ & 0 \\
\hline Hermes T2 & $92,098 \mathrm{ab}$ & $20.41 \mathrm{~b}$ & $3.08 \mathrm{~b}$ & $50.36 \mathrm{~b}$ & $0.288 \mathrm{~b}$ & $85.6 \mathrm{~b}$ & $9.59 \mathrm{ab}$ & $6.31 \mathrm{a}$ & 0 \\
\hline $\begin{array}{l}\text { Lady Amarilla } \\
\text { Control }\end{array}$ & $73,307 \mathrm{a}$ & $13.75 \mathrm{a}$ & $2.41 \mathrm{a}$ & $50.95 \mathrm{a}$ & $0.185 \mathrm{a}$ & $76.83 \mathrm{a}$ & $11.89 \mathrm{a}$ & $15.55 \mathrm{~b}$ & 28.56 \\
\hline $\begin{array}{l}\text { Lady Amarilla } \\
\text { T1 }\end{array}$ & $72,529 \mathrm{a}$ & $24.83 \mathrm{~b}$ & $4 \mathrm{~b}$ & $52.51 \mathrm{a}$ & $0.232 \mathrm{~b}$ & $89.34 \mathrm{~b}$ & $9.38 \mathrm{a}$ & $7.1 \mathrm{a}$ & 1.19 \\
\hline $\begin{array}{l}\text { Lady Amarilla } \\
\text { T2 }\end{array}$ & $76,338 \mathrm{ab}$ & $25.25 \mathrm{~b}$ & $4.66 \mathrm{~b}$ & $53.03 \mathrm{a}$ & $0.222 \mathrm{~b}$ & $83.13 \mathrm{~b}$ & $10.32 \mathrm{a}$ & $9.75 \mathrm{a}$ & 2.38 \\
\hline
\end{tabular}

*Different letters in the same column per cultivar indicate significant differences $(\mathrm{p}<0.05)$ 
As it is showed in Table 2, both T1 and T2 significantly increased control productions in Agria and Hermes cultivars. Moreover, the compost tea increased potato mean yield by $9.47 \%$ for the T2 and by $3.32 \%$ for the T1 dose. Even, in the Agria cultivar was got an increase value of $16.44 \%$ for T2. This fact reached up to 11 tons more production per hectare. It can also be observed a major number on stems in plants with compost tea application than in control.

Although it did not increase the number of tubers, the compost tea got up the tuber size and weight. Concretely, the tuber size was higher than control by $22.29 \%$ for $\mathrm{T} 1$ and by $17.96 \%$ for $\mathrm{T} 2$. The increase of tuber weight was significantly higher than control for the both compost tea dosages. Likewise, the improvement in potato weight reached on average of 68.33 and $76.67 \mathrm{~g}$ for the $\mathrm{T} 1$ and T2, respectively. The effect as fertilizer of compost tea can be a reference for its use in ecological and conventional agriculture.

On this way, the analysis of the growth effect on tomato plants clearly indicates that compost tea when applied every two weeks produce a positive effect on tuber caliber, number of shoots, yield and fried quality compared to that on control plants. This improvement by using compost teas corroborates previous studies (Hargreaves et al., 2009; Marín et al., 2014). Pant et al. (2009; 2012) found a positive influence on the growth of Brassica rapa with the minerals of compost tea. This finding is in agreement with our results in which $\mathrm{N}$, $\mathrm{K}$ levels together humic acids composition could be the principal explanations for the growth effect on potato plants.

In Figure 1, the results of the culinary tests are showed. It is observed a decrease in the level of average frying defects of $20.47 \%$ for $\mathrm{T} 1$ and $17.01 \%$ for the T2 with respects to the controls. This fact is especially important in Agria cultivar in which a reduction in the percentage of frying defects of $40 \%$ was achieved.

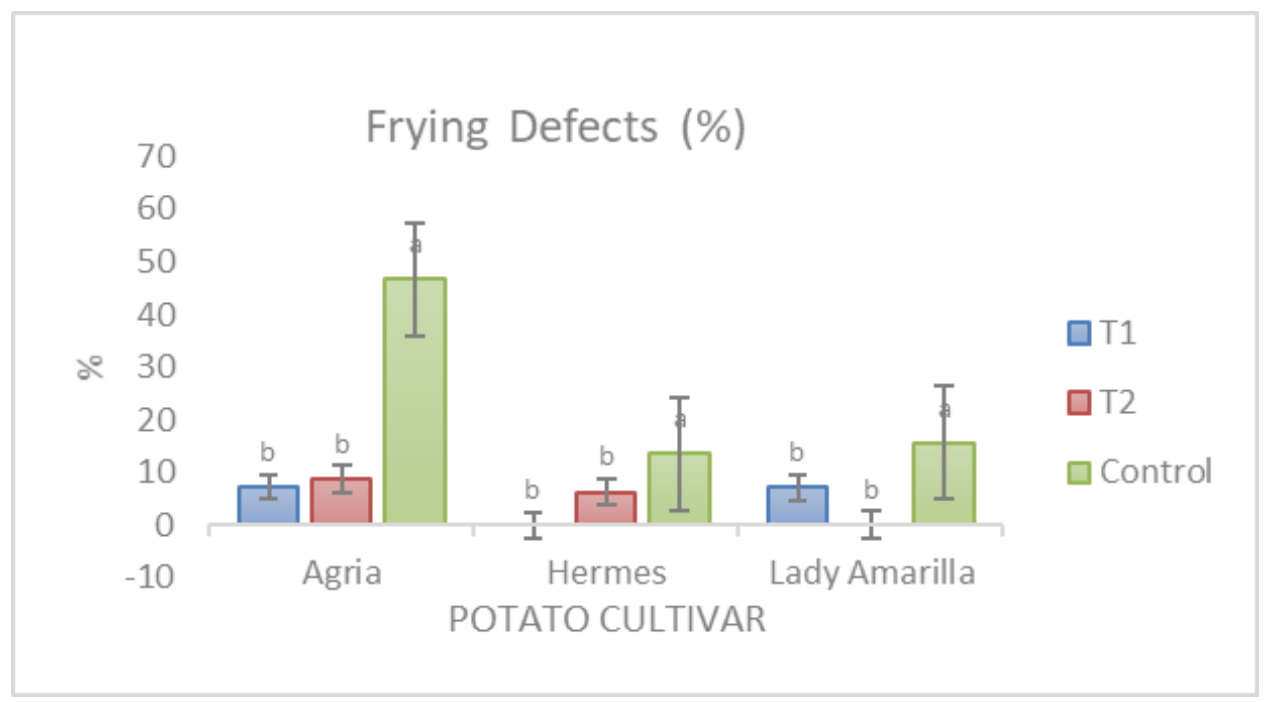

Figure1. Percentage of frying defects in potatoes treated with compost tea. 
The attack severity of Rhizoctonia is showed in Figure 2. Lady amarilla control suffered an important incidence which was reduced by application of compost tea both $\mathrm{T} 1$ and $\mathrm{T} 2$ dosages. Also, Rhizoctonia affection was controlled for Agria and Hermes cultivars where compost tea was applied (0\% infected plants). Gómez-Sánchez et al. (2017) also confirm the effect of compost tea on controlling the pathogen in pot-trials. These authors consider that the effect is caused by the microbiological activity of garden waste compost tea.

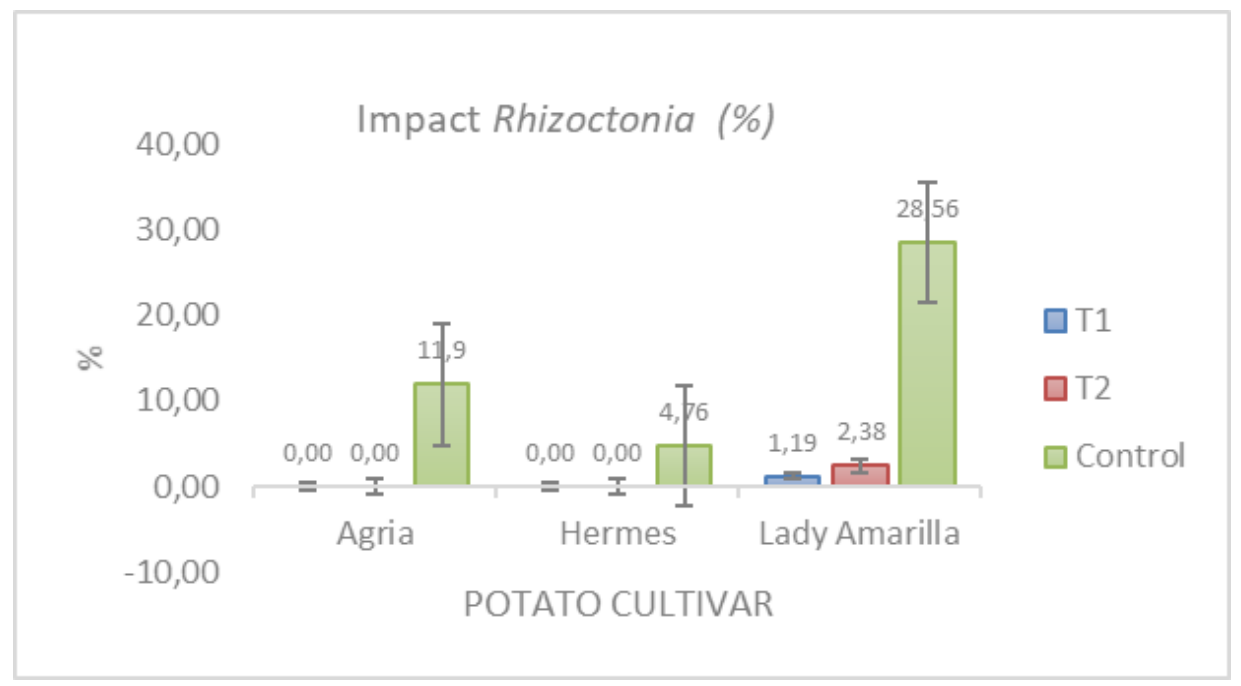

Figure 2. Impact of Rhizoctonia solani on potato cultivars treated with compost tea

Positive control of the pathogen was reported by Weltzien (1989) using composted organic materials, particularly green residues. Authors, such as Suárez-Estrella et al. (2012) and Tian and Zheng (2013), analysed in vitro the suppressive effect of different compost teas. The biocontrol of different crops has been studied (Tateda et al., 2012 and Pane et al., 2013), wherein the level of pathogenicity of $R$. solani was reduced using different compost teas.

Diánez et al. (2007) reported that lignocellulosic wastes induce specific suppression of $R$. solani by Trichoderma spp., which are often present in garden waste mature compost. Additionally, Krause et al. (2001) related the suppression of $R$. solani to the presence of microbial antagonism in the compost. These results are in line with our study in which a clear suppressive effect on $R$. solani was obtained compared to the controls when using $\mathrm{T} 1$ and $\mathrm{T} 2$ dosages of compost tea.

\section{CONCLUSIONS}

The obtained results show that the application of compost tea in potato culture can be of great interest as a biofertilizer and for the Rhizoctonia solani control. 
The waste of gardening can go from a residue to a very valuable resource for using in agronomy by composting and their after obtaining a tea. These trials should be repeated in a new campaign to corroborate the results.

\section{REFERENCES}

Al-Dahmani J.H., Abbasi P.A., Miller S.A., Hoitink H.A.J, (2003). Suppression of bacterial spot of tomato with foliar sprays of compost extracts under greenhouse and field conditions. Plant Dis. 87: 913-919.

Bollo E. (1999). Lombricultura: una alternativa de reciclaje. Quito. Soboc Grafic. 149 p.

Diánez, F.; Santos, M.; Tello, J.C. (2007). Suppressive effects of grape marc compost on phytopathogenic oomycetes. Archives of Phytopathology and Plant Protection 40: $1-18$.

Food and Agriculture Organization [FAO]. (2016). Faostat: agriculture data. Available at: http://faostat3.fao.org/faostat-gateway/go/to/download/ [Accessed Dic 15, 2017]

Gómez-Sanchez, M.A., Morales.Corts, R, Pérez-Sanchez, R, López-Martín, J.J. (2017). Estudio del valor agronómico del té de compost de residuos de jardinería en el cultivo de patata (Solanum tuberosum L.) y su efecto supresor sobre Rhizoctonia solani Kühn. Actas de la Red Española de Compostaje. 178-183 pp.

Hargreaves, J.C.; Adl, M.; Warman, P.R. (2009). Are compost teas an effective nutrient amendment in the cultivation of strawberries? Soil and plant tissue effects. Journal of the Science of Food and Agriculture 89: 390-397.

Krause, M.S.; Madden, L.V.; Hoitink, H.A. 2001. Effect of potting mix microbial carrying capacity on biological control of Rhizoctonia damping-off of radish and Rhizoctonia crown and root rot of poinsettia. Phytopathology 91: 1116-1123.

Labrador M.J., 2001. La Materia Orgánica en los Agroecosistemas. Grupo Mundi-Prensa. España. 169-171 pp.

Marín, F.; Diánez, F.; Santos, M.; Carretero, F.; Gea, F.J.; Castañeda, C.; Navarro, M.J.; Yau, J.A. (2014). Control of Phytophthora capsici and Phytophthora parasitica on pepper (Capsicum annuum L.) with compost teas form different sources, and their effects on plant growth promotion. Phytopathology Mediterranea 53: 216-228.

Martin, C.C.S. 2014. Potential of compost tea for suppressing plant diseases. CAB Reviews 9: 1-38.

Martínez C., 1996. Potencial de la lombricultura: elementos básicos para su desarrollo. A. Carballo; S. Bravo (eds). Texcoco, MX. 140 p.

Masciandaro G., Ceccanti B., Rnchi V., Bauer, C. (2000). Kinetic parameters of dehydrogenase in the assessment of the response of soil to vermicompost and inorganic fertiliser. Biology and Fertility of Soils 32, 479-483.

Morales-Corts., M.R., Pérez-Sánchez, R., Gómez-Sánchez, M.A. (2018). Efficiency of garden waste compost teas on the tomato growth and suppressiveness against soilborne pathogens. Scientia Agricola 75 (5): 361-443

Pane, C.; Piccolo, A.; Spaccini, R.; Celano, G.; Villecco, D.; Zaccardelli, M. (2013). Agricultural waste-based composts exhibiting suppressivity to diseases caused by the phytopathogenic soil-borne fungi Rhizoctonia solani and Sclerotinia minor. Applied Soil Ecology 65: 43-51.

Pant, A.P.; Radovich, T.J.; Hue, N.V.; Talcott, S.T.; Krenek, K.A. (2009). Vermicompost extracts influence growth, mineral nutrients, phytonutrients and antioxidant activity in pak choi (Brassica rapa cv. Bonsai, Chinensis group) grown under vermicompost and chemical fertiliser. Journal of the Science of Food and Agriculture 89: 2383-2392. 
Pant A.P., Radovich K.T.J., Hue V.N., Paull E.R. (2012). Biochemical properties of compost tea associated with compost quality and effects on pak choi growth. Sci Horticulturae 148:138-146.

Reeve, J.R.; Carpenter-Boggs, L.; Reganold, J.P.; York, A.L.; Brinton, W.F. 2010. Influence of biodynamic preparations on compost development and resultant compost extracts on wheat seedling growth. Bioresource Technology 101: 56585666.

Suárez-Estrella, F.; Bustamante, M.; Moral, R.; Vargas-García, M.; López, M.; Moreno, J. (2012). In vitro control of Fusarium wilt using agroindustrial subproduct-based composts. Journal of Plant Pathology 94: 59-70.

Tian, X.; Zheng, Y. (2013). Compost teas and reused nutrient solution suppress plant pathogens in vitro. HortScience 48: 510-512.

Tateda, M.; Yoneda, D.; Sato, Y. (2012). Effects of Compost Tea Making from Differently Treated Compost on Plant Disease Control. JSPS/VAST, Osaka, Japan.

Tognetti C., Laos F., Mazzarino M.J., Hernández M.T. (2005). Composting vs vermicomposting: A comparision of end product quality. Comp. Sci. util. 13(1):613.

Weltzien, H. C. (1991). Biocontrol of foliar fungal diseases with compost extracts. In: Andrews, J. H., Hirano, S. S. (Eds.). Microbial ecology or leaves. SpringerVerlag, NewYork, ppl 430-450. 